See discussions, stats, and author profiles for this publication at: https://www.researchgate.net/publication/336344240

\title{
The Role of Teachers in Utilizing Learning Media as A Learning Source for
} Millenial Students

Conference Paper · January 2019

DOI: 10.4108/eai.30-7-2019.2287549

\section{CITATIONS}

3 authors, including:

Ezra Tari

STAK Negeri Kupang (Kupang State Christian College)

30 PUBLICATIONS OCITATIONS

SEE PROFILE

Some of the authors of this publication are also working on these related projects:

Project Koloqoium Perjanjian Baru View project 


\title{
The Role of Teachers in Utilizing Learning Media as A Learning Source for Millenial Students
}

\author{
Talizaro Tafonao ${ }^{1}$, Setinawati ${ }^{2}$, Ezra Tari $^{3}$ \\ \{talizarotafonao@gmail.com ${ }^{1}$, setinawatistn@gmail.com ${ }^{2}$, tariezra@gmail.com ${ }^{3}$ \} \\ ${ }^{1}$ Sekolah Tinggi Teologi KADESI Yogyakarta, Indonesia \\ ${ }^{2}$ Sekolah Tinggi Agama Kristen Negeri Palangka Raya, Indonesia \\ ${ }^{3}$ Sekolah Tinggi Agama Kristen Negeri Kupang, Indonesia
}

\begin{abstract}
In this writing, the author does a study about the role of teachers in utilizing learning media as a source of learning for millennial students. This study departs from the anxiety of the author about the condition of the teachers in the digital era. The author sees that at this time some teachers have difficulties in dealing with millennial students. Based on this problem, the authors do a study about the role of teachers in utilizing learning media empirically. Based on the study which did by the authors in this paper, three important point must be done by teachers in dealing with millennial students, that are: first, teachers can take advantage of all forms of technological development. Technological progress is something that cannot be avoided in this life, so the teacher should not be allergic to all forms of development that exist. Second, teachers can understand the power of the media as a source of learning. The benefit of learning media is determining the quality of learning delivered by a teacher. Therefore, teachers need to prepare learning media before teaching in class. After that, the teacher has to understand the needs of the millennial students. The needs of millennial students are not the same, but at least the presence of teachers provides solutions both cognitive, affective and psychomotor. The uniqueness of the teacher, in this case, is a teacher can act as anything as long as it can influence student behavior towards positive actions, even those students can become actors of the progress of the media. This is evident from the student activities that have been narrated in this paper
\end{abstract}

Keywords: Teacher, media, millennial students.

\section{Preliminary}

Today humans have existed in a millennial era where technology has mastered the life of society, nation, and state. The proof is the younger generation can not be separated from social media. According to "Data from Badan Pusat Statistik in 2011-2015 was recorded for the 2564 year age group, 79.02 percent of internet users live in urban areas and only 20.98 percent of the rural population liked to surf the network (online). The distribution based on the sex of internet users in 2015 was 59.08 percent male and 40.92 percent female. Especially for urban areas, the amount of data of residents aged 25-64 years on the internet is 22.87 percent of women and 31.37 percent of men":[1].

The people involved in this activity are named millennial. Because this generation is accompanied by a style of modernization called contemporary (modern) compared to previous generations. To get to know that "Millennial generation or also called Generation Y was born around 1980 to 2000. So the millennial generation is the current generation of young people who in this era are around 15-34 years old. The age range is following the average age of 
students who are studying in college, which is around 19-34 years old:[2]. Thus "this generation can be interpreted as a group of people who have different characteristics from each other, the main difference is the year of birth. Because of the difference in the year of birth which makes it different between generations that each generation of humans lives in different times and the development of information technology too:[3]. It can be said, the millennial generation is a generation that is "technology literate". Now, millennial generations are faced with situations where everything is easy to access. In fact, the term "the world is in your grasp" is often heard or there is also the term "world in your fingertips".

The effects of the development of information technology are the number of millennial students who depend on their gadgets is not a little amount so that they no longer focus on learning that is being studied at school. In other words, technological advances have diverted the attention of students to take advantage of each of these technological advancements. However, it must be acknowledged that "technological developments have provided convenience to every child in obtaining all information, communicating and at the same time supporting the smooth activities in completing existing tasks using the internet and gadgets:[4]. But on the other side, many students have misused technology unwisely. For example: using social media to watch pornographic sites, spread hatred/ hoax to someone.

These things are a big challenge in the learning process at school. For this reason, the role of teachers in utilizing learning media is very important to influence this next generation to positive things. According to Nurmadiah \& Nurmadiah that "the use of media in classroom teaching is a necessity that cannot be ignored. This can be understood considering the learning process experienced by students is based on various activities to increase knowledge and insight for the provision of life in the present and the future:[5]. According to Nursamsu \& Kusnafizal (quoted in Danim, 2011) "technology-based learning media can make learning more powerful where communication contacts between individuals supported by technology can add value in certain communication skills. The use of media in the teaching and learning process is not an additional function, but has its function as a tool:[6].

Based on the explanation above, it can be concluded that in increasing a student's interest in learning is not an easy thing. Students who live in the millennial era who are already accustomed to advanced technology will be very difficult in educating by using ancient methods that are only lecturing. But with the creativity and innovation which is always built by the teacher through the media technology can be overcome properly. In the opinion of Falahudin, Iwan (quoted in Wiratmojo, $P$ and Sasonohardjo, 2002) "the use of learning media in the teaching and learning process can generate new interests and desires, generate motivation and stimulation of learning activities, and even bring psychological influences to students. The use of learning media at the teaching orientation stage will greatly help the effectiveness of the learning process and the delivery of messages and content of the lesson at that time:[7].

Therefore, to deal with students who are accustomed to this technology, educators must also master technologies that can be used as learning media. So that it can establish a good process of interaction in learning. But in practice, there are still many educators who have not maximized themselves in utilizing learning media as a source of learners who are very active in carrying out the teaching and learning process. This happens for various reasons, according to the author's description in one of the articles that there are several reasons, why do teachers not use learning media. The first reason is (1). The teacher considers that using media needs preparation. (2). Media is a sophisticated and expensive thing. (3). They do not usual to use media (technology stutter). (4). Media is only for entertainment while learning must be serious. (5). In the school there is not such available media, the school does not have the 
equipment and materials to make learning media. (6). The teacher does not understand the importance of using learning media. (7). The teacher does not have the knowledge and ability on how to make his own learning media. (8). The teacher does not have a skill to use learning media. (9). The teacher does not have the opportunity (time) to create learning media. (10). Teachers are used to relying on the lecture method:[8].

Even though the use of technology media strongly supports the teaching and learning process, helping educators explain things that are difficult to just explain verbally, and also help attract the attention of students. Preferably, educators do not need to be allergic to the use of technology as a learning media. Therefore, the role of the teacher in innovation and the development of learning media is very important because the teacher plays a role in the teaching and learning process in the classroom. So from that a teacher is required to be able to process his ability to make learning media more effective and efficient so that learning can be more fun. In other words, "the primary responsibility of the teacher is to codify a pleasant learning environment so can arouse curiosity of all students so that they grow interested in learning:[9].

\section{Theoretical study}

\subsection{The definition of role of the teacher and learning media}

A Role is a form of behavior expected of a person in certain social situations. Role becomes meaningful when associated with others. According to Sarlito Wirawan Sarwono the term of "role" is commonly used in the world of theater, where an actor in the theater must play as a certain character and in his position as a character he is expected to behave in a certain way. The position of an actor in the theater is analogous to the position of someone in society, and both have similar positions". The purpose of the role is a teacher can act as a mentor to students. According to Alwi Said "the role of the teacher is the key to success in developing the mission of education and teaching in schools in addition to being responsible for regulating, directing and creating a conducive atmosphere that encourages students to carry out activities in the classroom:[9].

While the word "media" according to Mahnu comes from the Latin Language "medium" which means "intermediary" or "introduction". Furthermore, the media is a means of channeling messages or learning information to be conveyed by the message source to the target or recipient of the message. The use of teaching media can help achieve learning success:[10]. The media in this topic is media that are highlighted from an educational perspective. Media in the education perspective is a very strategic instrument in determining the success of the teaching and learning process. This is due to its existence which can directly provide its own dynamics towards students. How come, according to Nurmadiah's explanation that "communication media contribute greatly to progress and quality improvement in an educational institution. By using these media students will easily digest and understand a lesson. Thus through a systematic scientific approach, and rational educational goals can be achieved effectively and efficiently:[11]. Also, the use of media in learning or also called media learning in the teaching and learning process can arouse new desires and interests, generate motivation and stimulation of learning activities, even bring positive psychological influences on students.

Based on the description above, the learning media are various types of tools used to convey messages in the teaching and learning process. This is the same as the opinion of Richad E. Mayer, who stated that Multimedia instruction is one of the current examples of a new area of instructional research and practice that has generated a considerable amount of 
excitement. (Learning media are one of the most recent examples of new areas of research and teaching practices that have produced a lot of excitement) (Mayer, 2015).

\subsection{The role of the teacher in utilizing learning media as a source of learning for millennial students}

The success or failure of learning in school depends on the media used by the teacher. The teacher becomes one of the spearheads in utilizing the media as well as a source of learning for millennial students. That is different in the past, teachers only used makeshift media, but in today's technological development, there is no reason for teachers do not to use learning media according to the needs of students. Moreover, millennial students are very close to the technology. This means that the teacher is not only as a teacher in front of the class and transfer knowledge to students, but about their role as a teacher who can demonstrate to his professionals in utilizing every available media. For this reason, "teachers are expected to be able to develop the skills in creating their own learning media, because of the development of science and technology is increasingly pushing towards renewal:[8].

Based on the explanation above, in this paper the author will describe some of the roles of teachers in utilizing learning media as a source of learning for millennial students are:

\subsubsection{Teachers can take advantage of all forms of technological development.}

As educators and mentors who equip millennial students certainly are not allergic to all forms of development that exist. All that can happen because being a teacher for students in the modern era is not an easy thing, the way of learning millennial students is very different from the way of learning children in ancient times. Students in ancient times were easily directed at learning because the source of learning at that time was the teacher. But ironically, the pattern of educating in ancient times is still found in today's digital era. For example, in one of non-public Colleges in the Special Region of Yogyakarta where the authors teach today, there are still lecturers who cannot use the facilities in laptop such as using power points and browsing from the internet. Finally, the lecturers only rely on makeshift dictates, not only that in the Odd semester of June-December 2018, some student complained to the author about lecturers who were still monotonous in teaching using media that was very minimal. So, students in the digital era have been formed and influenced by technological developments. Just look at the lifestyle of students in this day and age, their social life can enjoy fast internet services.

Not only enjoy the sophistication of the technology but can do anything through smartphones, ranging from entertainment, learning and working. This means that "technological progress is something that cannot be avoided in this life, because technological progress will run together:[12]. In dealing with these various problems, the teacher's role must be increased in following various technological developments to overcome various obstacles in utilizing learning media. This reason was conveyed by Soewarno (quoted in Nasution, 2010: 109) who argue that "teachers play an important role in the development of educational technology so they must try to learn how to use it:[13]. He continued to say that modern education technology is not the enemy of the teacher but as a teacher's helper to improve the efficiency and effectiveness of the teaching and learning process. Therefore, the latest technology must be designed in such a way by the teacher, the knowledge and skills of the teacher must always be improved, and various learning facilities that can be utilized from various available sources to avoid the low public trust in educational services that held in schools. 


\subsubsection{Teachers can understand the power of media as a source of learning}

In utilizing learning media, it determines the quality of learning which is delivered by a teacher, because in general media is a tool that can be used to convey information to each student (recipient of the message). For this reason, learning media certainly needs serious attention from the instructors because the media has an important role in generating desire, interest, motivation and stimulating the minds of students to learn. However, in utilizing the media, media must be selected according to the standards of competence and indicators that are set. Choosing the best learning media for competency standards and indicators of learning is not an easy job. Because the selection of media is based on various principles and factors that influence each other.

Not only that, according to Lestari's explanation who said "the selection of methods and learning media will determine the success of the teacher in the learning process in the classroom. The use of learning media can influence motivation, communication and student learning interactions to respond more and interactively in learning activities in the classroom:[14]. In other words, learning media has the power that can make a person survive to pay attention to every material studied. One of the activities that were attended by the author was the National Seminar with the Theme "Capability of Educators in the Digital Age" which held by the Ikatan Dosen Republik Indonesia (IDRI) at the LLDikti Building in Region V of Yogyakarta Province on February 23, 2019. At that seminar some speakers discuss the topic which prepared by the committee, but it is very unfortunate because some speakers who present the material without using any media even though the material of the seminar is very good. As a result of the lack of utilizing the media as a source of learning, the participants at that time no longer focused on paying attention to each of the material described. Some participants often walk in and out of the room because they were tired of hearing the speakers in front.

By learning that event above, it invites all educators to look at the definition of the media. If the media as a source of learning, the teacher will agree with the opinion that described by Iwan Falahudin (quoted in Kemp \& Dayton, 1985) that the media have an important role in the teaching and learning process including: (1) Synchronizing the subject which is delivered. (2) Making the teaching and learning process clearer and more interesting. (3) Making the learning process more interactively. (4) Make time and energy-efficient. (5) Improve the quality of learning outcomes. (6) Allows the learning process to be carried out anywhere. (7) Growing a positive attitude towards the material and learning process. (8) Change the role of educators in a more positive and productive direction. (9) Making abstract subject more concrete. (10) Overcoming the limitations of space and time. (11) Helps overcome the limitations of the human senses:[7]. With the explanation above, it can be concluded that learning media is an important role in the teaching and learning process.

\subsubsection{Teachers understand the needs of millennial students}

Students in the millennial era spend much of their time by playing gadgets such as Instagram, Facebook, Whats App, Games, and others. The gadget has changed its function, first the cellphone is only used for telephone and send a message to ask about family or people who are known, but in its development this mobile phone is no longer functioned as a communication tool but rather a lifestyle to be exhibited. Not only that, the sophistication of this technology can make it easier for students to get knowledge from various parts of the world quickly and easily. One real example faced by the author is when the author taught in 
the odd semester June-December 2018, at that time several students complained about paper assignments that had not been resolved for reasons that there were not enough references so the paper was not collected at the time. The author as an educator certainly does not only hear the complaint, but the author gives a solution. One solution is the writer tells students how to find references about journals and books from the internet (Google).

Even though, in the view of Iffah Al Walidah said that "the millennial generation who are internet users are generally less able to sort information. Today there seems to be a tendency for internet users who often exclude moral and ethical values in communicating and disseminating information on social media:[15]. Based on Walidah's statement above there is the truth but the author disagrees with her because it needs to be considered in terms of the psychology of the students. The author intends that not all students in the digital age are currently involved in the crime as mentioned above. The proof was when the author had a meeting with one of the students of Taman Siswa Yogyakarta University who her name is Elisabet with the Department of English Literature on June 2, 2019. That fifth semester students expressed that feel happy with the advancement of technology in this era because there are many things that can be done and shared to other people through video in English which she has compiled with a duration of 2 minutes then uploaded on his instragram, then many people who like her even her lecturer and her head of study program very support of the creativity she did.

The lecturers are not only supported but the lecturers can also guide them according to the skills that they have. In this conversation, the author concludes that the presence of the instructors in the classroom is not merely demanding that each student work on a pile of tasks that must be done but educators should be the helper of millennial students in fulfilling their needs. Students in the present era have various characteristics. One of the characteristics of millennial students who stand out is that they are not controlled, do not want to be bound by additional schedules, do not really like the atmosphere of the class which is always monotonous. Preferably, the teacher must immediately change his teaching from authoritarian to more flexible. According to Sidjabat's understanding that "the teacher is a bridge, as well as an agent that allows students to dialogue with their world. That is an important call for every teacher is to encourage students to gain knowledge, understanding, or even contribute to their world: (Sidjabat, 2017).

Therefore, teachers are required to have creativity and innovation that can support the ability of students to use the media as a learning resource. For this reason, there are several roles of teachers in dealing with millennial students, that are : (1). The teachers should have open-minded to the students in facing the development of the digital world. (2). The teachers should help students to be able to use social media as needed. (3). The teachers demonstrate proficiency in the technology system and transfer knowledge of new technologies and situations. (4). Teachers can collaborate with students in using technology as a learning resource. So the role of the teacher is to be willing to wholeheartedly become a guide for the next generation is facing the times.

\section{Conclusion}

In the development of technology media, especially in the digital era, it can provide great benefits to teachers to use that as learning resources. But in fact, the progress of technology media that is getting faster and faster can not be properly expressed by millennial educators as explained earlier, even the teachers are trapped in their inability to follow the various developments that exist today. This can be seen from the attitude of the teacher who is still 
closed to the development of the digital world under the pretext of being old and not the age to learn things like that. This progress is not a threat to the teacher but as an effort to make it easier to understand the outside world that has never been visited by his. With the existence of this media becomes a tool to introduce these things to all students about any things which happen today or going to happen in the future.

This paper can be a contribution for teachers in dealing with millennial students in Indonesia by using a study of the role of teachers in utilizing learning media. However, this study is an analyze contribution that are for the person of a teacher, but the contribution is for the activity as a teacher who can face all the challenges that exist in his day. Thus, this study can contribute optimally to building an efficient learning atmosphere, so students become superior and competitive graduates.

\section{References}

[1] G. Arianti, "Kepuasan Remaja Terhadap Penggunaan Media Sosial Instragram Dan Path,"WACANA, J. Ilm. Ilmu Komun., vol. 16, no. 2, pp. 180-192, 2017.

[2] Hidayatullah, Syarif, Waris, Abdul, Devianti, and R. Chris, "Perilaku Generasi Milenial dalam Menggunakan Aplikasi Go-Food," J. Manaj. Dan Kewirausahaan, vol. 6, no. 2, pp. 240-249, 2019.

[3] P. Panjaitan and A. Prasetya, "PENGARUH SOCIAL MEDIA TERHADAP PRODUKTIVITAS KERJA GENERASI MILLENIAL (Studi Pada Karyawan PT . Angkasa Pura I Cabang Bandara Internasional Juanda ),” J. Adm. Bisnis, vol. 48, no. 1, pp. 173-180, 2017.

[4] T. Tafonao, "PERAN PENDIDIKAN AGAMA KRISTEN DALAM KELUARGA TERHADAP PERILAKU ANAK," Edudikara J. Pendidik. dan Pembelajaran, Vol 3 (2), 2018 ISSN 2541-0261, vol. 3, no. 2, pp. 121-133, 2018.

[5] N. Nurmadiah, "Media Pendidikan," Al-Afkar J. Keislam. Perad., vol. 5, no. 1, pp. 131-144, 2018.

[6] Nursamsu and T. Kusnafizal, "Pemanfaatan Media Pembelajaran Ict Sebagai Kegiatan Pembelajaran Siswa Di Smp Negeri Aceh Tamiang," J. IPA dan Pembelajaran IPA (JIPI), 1(2) 165-170, Desember 2017 www.jurnal.unsyiah.ac.id/jipi p-ISSN 2614-0500, vol. 1, no. 2, pp. 165-170, 2017.

[7] I. Falahudin, "Pemanfaatan Media dalam Pembelajaran," Lingk. widyawiswara, 2014.

[8] T. Tafonao, "PERANAN MEDIA PEMBELAJARAN DALAM MENINGKATKAN MINAT BELAJAR MAHASISWA,” J. Komun. Pendidikan, Vol.2 No.2, Juli 2018 PISSN 2549-1725 E-ISSN 2549-4163, vol. 2, no. 2, 2018.

[9] S. Alwi, "PROBLEMATIKA GURU DALAM PENGEMBANGAN MEDIA PEMBELAJARAN," Itqan, vol. 8, no. 2, pp. 145-167, 2017.

[10] N. Mahnun, "Media Pembelajaran (Kajian terhadap Langkah-langkah Pemilihan Media dan Implementasinya dalam Pembelajaran)," J. Pendidik. Islam, 2012.

[11] N. Nurmadiah, "MEDIA PENDIDIKAN: Peran dan Fungsinya dalam Pembelajaran," Al-Afkar J. Keislam. Perad., 2018.

[12] M. Ngafifi, "Kemajuan Teknologi Dan Pola Hidup Manusia Dalam Perspektif Sosial Budaya," J. Pembang. Pendidik. Fondasi dan Apl., vol. 2, no. 1, pp. 33-47, 2014.

[13] Soewarno, Hasmiana, and Faiza, "Kendala-Kendala Yang Dihadapi Guru Dalam Memanfaatkanmedia Berbasis Komputer Di Sd Negeri 10 Banda Aceh," J. Pesona Dasar, vol. 2, no. 4, pp. 28-39, 2005.

[14] I. D. Lestari, "Peranan Guru Dalam Penggunaan Media Pembelajaran Berbasis 
Information And Communication Technology (ICT) Di SDN RRI Cisalak," SAP (Susunan Artik. Pendidikan), vol. 3, no. 2, pp. 137-142, 2019.

[15] I. Al Walidah, "Tabayyun di era generasi millennial," J. LIVING HADIS, Vol. 2 Nomor 1, Oktober, 2017; p-ISSN 2528-756; e-ISSN 2548-4761, hal 317-, vol. 2, pp. 317-344, 2017. 